\title{
Sustainable Life and Social Development through Universally Designed Environment
}

\author{
Syazwani Abdul Kadir ${ }^{1}$, Mariam Jamaludin² \\ ${ }^{1}$ Centre for Environment-Behaviour Studies, ${ }^{2}$ Faculty of Architecture, Planning and Surveying, \\ Universiti Teknologi MARA, Malaysia \\ *syazwani@uwalumni.com
}

\begin{abstract}
Universally designed environment provides comfort, adaptability and flexibility that can help to reduce human life cycle impact and encourage residents' participation in the community. With that, the purpose of this conceptual study is to explore the concept of Universal Design (UD) as a significant aspect of social sustainability, based on professional practitioners' and scholarly views. UD implementation in built environment may cater the needs of diverse users over the changing abilities throughout lifespan. This study concludes that UD has evolved as a significant component for sustainable life and social development within the individual's own dwelling and the community as well.
\end{abstract}

Keywords: Universal Design; social sustainability; sustainable life; social development

eISSN 2514-751X @ 2018. The Authors. Published for AMER ABRA cE-Bs by e-International Publishing House, Ltd., UK. This is an open-access article under the CC BY-NC-ND license (http://creativecommons.org/licenses/bync-nd/4.0/). Peer-review under responsibility of AMER (Association of Malaysian Environment-Behaviour Researchers), ABRA (Association of Behavioural Researchers on Asians) and cE-Bs (Centre for EnvironmentBehaviour Studies), Faculty of Architecture, Planning \& Surveying, Universiti Teknologi MARA, Malaysia.

DOI: https://doi.org/10.21834/aje-bs.v5i17.49 


\subsection{Introduction}

The crucial agenda of 21st century design, sustainability, can be categorized to three main aspects; environmental, economic and social. Much emphasis have been given to the environmental and economic aspects in the discussion of mainstream sustainability, however, the social sustainability which is equally important has often been neglected (Woodcraft, Hackett \& Caistor-Arendar, 2011). Social sustainability relates to how the environment influences human quality of life, thus, a socially sustainable built environment should be created through smart planning and design.

World Commission on Environment and Development (1987) describes sustainable design as the guiding concept to create the built environment that "meets the needs of the present without compromising the ability of future generations to meet their own needs." This study therefore proposes that Universal Design (UD) is an approach that may help to accomplish those goals of sustainable design. With UD, the built environment may be able to cater the needs of its present users and sustain the inclusivity for future communities.

This conceptual paper discusses how UD implementation in built environment may contribute to social sustainability through the inclusive living spaces and livable public realms. The purpose of this study is to explore the concept of UD as a significant aspect in social sustainability, particularly in regards to sustainable life and social development. Method applied for this study is review of secondary data by scholars and professional practitioners. Nevertheless, it is acknowledged that since the study is being limited by one side of resource, it can be complemented by other methods such as observation and interviews in future researches.

Despite the limitation, this study hopes to contribute to the knowledge of social sustainability in mainstream debates. This paper will, first, present the evolving criteria of social sustainability, followed by the elaboration on how UD can foster sustainable life and social enhancement.

\subsection{Literature Review}

\subsection{Social Sustainability And Its Relation To Universal Design}

\subsubsection{The Underlying Elements of Social Sustainability}

With respect to the built environment, Young Foundation identifies social sustainability as "a process for creating sustainable, successful places that promote wellbeing, by understanding what people need from the places they live and work. Social sustainability combines design of the physical realm with design of the social world - infrastructure to support social and cultural life, social amenities, systems for citizen engagement and space for people and places to evolve" (Woodcraft, Hackett \& Caistor-Arendar, 2011). To complement the definition, this paper would like to suggest that, in addition to the social development within a community, life cycle and growth of the individuals within their private living spaces are also significant as the underlying elements of social sustainability.

Home is where an individual grows physically, develops essential values as a human 
being and builds a family. In a broader context, a single home is what creates a neighbourhood, and an individual is what composes a community. Social sustainability, thus, can be implied as the collective process of life growth and interaction among humans within their surrounding environment, which evolves from private domain to the public living environment.

\subsubsection{The Emerging Criteria for Social Sustainability}

Many studies have been done as to develop a list of criteria which may help researchers to measure social sustainability of a community. According to Colantonio (n.d.), the traditional themes of social sustainability such as poverty mitigation and employment rate are slowly substituted by the more subjective themes such as sense of place, social participation and happiness.

Sharifi and Murayama (2012) review recent criteria for social sustainability as listed in Table 1. In general, Table 1 indicates that the emerging measures for social sustainability include health and well-being, safety and security, access to facilities and amenities, participation, and social interaction (Sharifi \& Murayama, 2012). These criteria can be accomplished through UD implementation in the built environment which provides space to grow and involve in the community.

Table 1: Criteria for Social Sustainability

\begin{tabular}{|l|l|}
\hline Author(s) & Criteria Considered \\
\hline $\begin{array}{l}\text { Spangenberg, } \\
2004\end{array}$ & $\begin{array}{l}\text { Income; communication and participation; education; social contacts; social security; distribution } \\
\text { of income and assets }\end{array}$ \\
\hline Choguill, 2008 & $\begin{array}{l}\text { Citizen participation; social interaction; feeling of belonging; interpersonal relations among the } \\
\text { neighborhood residents; collective action; mutual support; access to facilities and amenities; } \\
\text { safety }\end{array}$ \\
\hline $\begin{array}{l}\text { Bramley et al., } \\
2009\end{array}$ & $\begin{array}{l}\text { Social equity; access to facilities and amenities; affordable housing; social interaction; safety/ } \\
\text { security; satisfaction with home; stability; participation in collective group/ civic activities }\end{array}$ \\
\hline $\begin{array}{l}\text { Colantonio, } \\
2009\end{array}$ & Equity; inclusion; adaptability; security \\
\hline Cuthill, 2010 & $\begin{array}{l}\text { Social Justice; social/community well-being; human scale development; engaged governance; } \\
\text { social infrastructure; community and/or human scale development; community capacity building; } \\
\text { human and social capital }\end{array}$ \\
\hline Dave, 2011 & $\begin{array}{l}\text { Access to facilities and amenities; amount of living space; health of the inhabitants; community } \\
\text { spirit and social interaction; safety; satisfaction with the neighborhood }\end{array}$ \\
\hline $\begin{array}{l}\text { Dempsey et al.,, } \\
2011\end{array}$ & $\begin{array}{l}\text { Social interactions; participation; community stability; pride and sense of place; social equity; } \\
\text { safety and security }\end{array}$ \\
\hline $\begin{array}{l}\text { Weingaertner \& } \\
\text { Moberg, 2011 }\end{array}$ & $\begin{array}{l}\text { Accessibility; social capital and networks; health and well-being; social cohesion and inclusion; } \\
\text { safety and security; fair distribution; local democracy, participation and empowerment; cultural } \\
\text { heritage; education and training; equal opportunities; housing and community stability; } \\
\text { connectivity and movement; social justice; sense of place; mixed use and tenure; attractive } \\
\text { public realm }\end{array}$ \\
\hline
\end{tabular}

(Source: Sharifi \& Murayama, 2012) 


\subsection{Sustainable Life Within The Private And Public Living Environment}

\subsubsection{Ud Relations To Sustainable Life}

This section discusses how a universally designed environment helps people to sustain their life within the private dwelling and the neighbourhood they live in. Sustainable life begins at home where the individual grows and develops as a person, a part of the family and as a member of the community. The living space and its surrounding areas very much influence the residents' quality of life; therefore, an enabling living environment is essential as to ensure a sustainable life.

Some of the evolving criteria for social sustainability which are related to sustainable life of an individual include well-being, safety, and access to facilities and amenities (Dave, 2011; Weingaertner \& Moberg, 2011). These criteria for sustainable life can be achieved through UD implementation in the planning and design process of housing and neighbourhood areas. Within adaptable private living spaces, an individual may develop sustainable well-being and a safe place to live in, while within accessible surrounding public realms, an individual may be able to run daily errands and accomplish life essential activities.

\subsubsection{Sustaining One's Life within the Private Residence}

During the late 20th century, housing design with adaptable features is still perceived by planners and designers as a specialized dwelling for PWD and elderly residents, not as an innovative living space usable by broad market users (Askalen et al., 1997). In this early 21st century, the universally designed home has been better recognized by professional architecture and interior design practitioners. This is shown by their increasing awareness on UD provision in housing built with the consideration of ecological sustainability.

Homes which were built with the most sustainable materials and appliances can become unsustainable if the design of the home cannot accommodate the needs of the households' diverse abilities (Skoda Design \& Architecture, 2012). Lawlor (2012) adds to that by saying that a sustainably built home can become emotionally and physically disabled if it cannot cater the changing needs of the households. An inaccessible home not only causes physical limitation to the disabled residents, but also emotional stress to live within an obstructive disabling environment. Therefore, considering the economic, environmental, and social sustainability, Skoda Design \& Architecture (2012) asserts that a truly sustainable home is the home that "can withstand the test of time, from using long-lasting and green materials, to accommodating the changing life stages of its residents."

Life cycle impact such as fatigue due to pregnancy or frailty due to ageing can be reduced by living in a home which is designed with usable appliances, comfortable furniture, and accessible spaces. A universally designed environment which provides adaptable and flexible space to live in may sustain one's life (Gold Coast City Council, n.d.). Duncan (2007) enhances this idea by saying that diverse users may benefit from UD through usable, safer and more comfortable environment which allows them to remain at a home as their abilities change over life span. Thus, it may be suggested that UD assists people to sustain their life by providing adaptable, flexible, safe and comfortable living spaces. 


\subsubsection{Sustaining One's Life within the Public Living Environment}

Looking at the broader extent of sustainable life, UD may also contribute to a sustainable life of the individual within the public living environment that provides accessible facilities and infrastructures. As one of the evolving criteria for social sustainability, the access to facilities and amenities is vital for the residents to run daily errands and perform different kind of life essential activities. For instances, an accessible public transportation enables users to commute to workplace, and an inclusive grocery market provides life necessities to the nearby residents. This ability to perform life essential activities should be sustained throughout a life span, even when the residents become temporarily impaired or age over time.

This idea of convenient living is also addressed by Town and Country Planning Association (TCPA) via their eco-town program in the United Kingdom. The program considers eco-town as an opportunity to create a responsive dwelling environment where all inhabitants, regardless of age, disability, faith or gender, can live comfortably and conveniently (TCPA, 2009). Convenient living and access to facilities and amenities are also the fundamental means to encourage participation and social interaction within a community, as elaborated in the next discussion.

\subsection{Social Development Within A Livable Community}

\subsubsection{UD Relations to Sustainable Social Development}

Another underlying aspect of social sustainability which may be fostered through a universally designed environment is the social development within a livable community. Social development can be identified as "one that is concerned with processes of change that lead to improvements in human well-being, social relations and social institutions, and that are equitable, sustainable, and compatible with principles of democratic governance and social justice" (UNRISD, 2011). An inclusive living environment may enable the individual to develop socially as a member of the community by being actively involved in the community over a lifetime, for instances, from being young kids at schools to being the elderly at an event at the community halls.

Among the emerging criteria for social sustainability which can be promoted via a universally designed environment are participation and social interaction (Choguill, 2008; Bramley et al., 2009; Dave, 2011; Dempsey et al., 2011; Weingaertner \& Moberg, 2011). Duncan (2007) claims that UD can be regarded as an element of social sustainability since it may create a supportive and enabling environment which fosters inclusive community involvement and nurtures social development.

\subsubsection{Fostering Social Development through the Components of Social Sustainability Framework}

To elaborate on social development of individuals within a livable community, this study utilizes the components of social sustainability framework by Young Foundation (Figure 1) as the means for a livable environment which promotes social interaction and participation. The four components of social sustainability framework are explained in relations to UD as 
to present the idea of social development through an enabling environment.

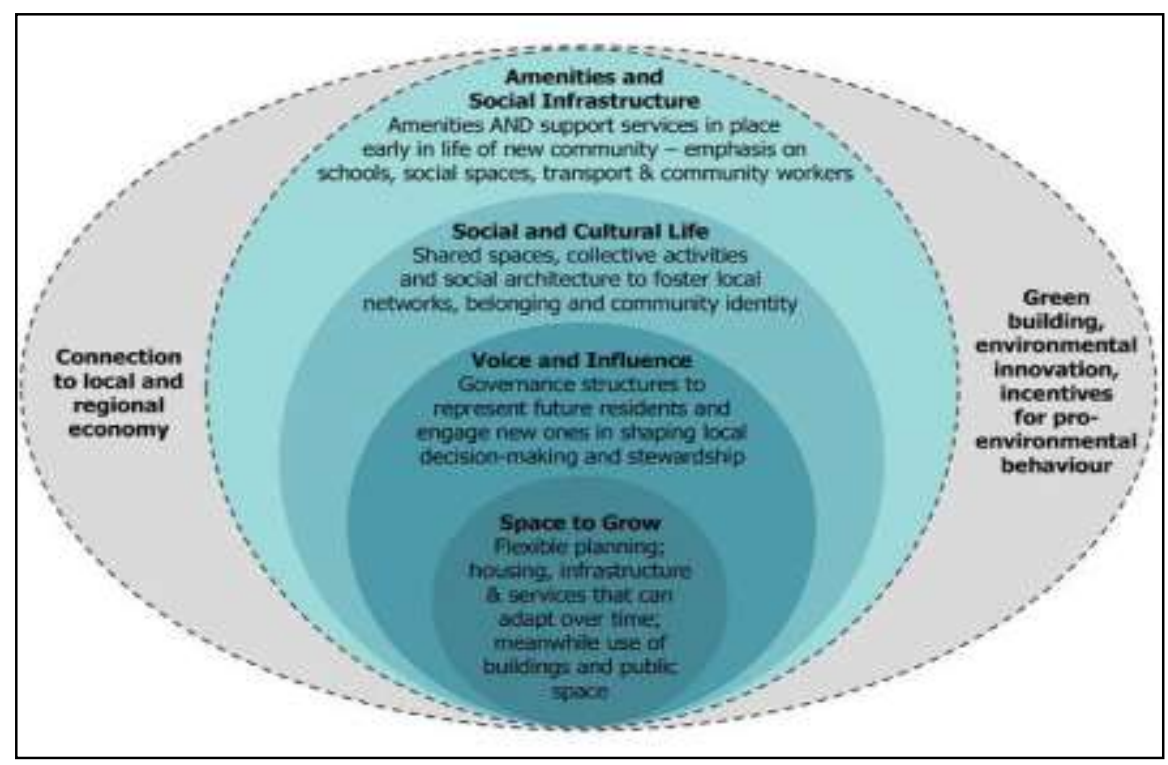

Figure 1: Illustration of Design for Social Sustainability Framework, Young Foundation(Source: Woodcraft, Hackett \& Caistor-Arendar, 2011)

\section{i. Amenities and Social Infrastructure}

The amenities provide support services for the community while the infrastructures allow connectivity in a neighbourhood or a city. To ensure a socially sustainable community, Woodcraft, Hackett and Caistor-Arendar (2011) establish that accessible amenities and social infrastructures need to be provided at the early stage of neighbourhood planning and design process. The access to amenities and social infrastructures also create visitability, which can be described as "the ability of individuals to freely interact, navigate, and integrate within their environments" (NCDDR, 2004).

Infrastructures such as public transportation and pedestrian pathways create walkability and connectivity within a neighbourhood, town or city. Rosly and Hashim (2011), in their presentation of "Guideline and Framework for Green Township in Malaysia," indicate that a sustainable town is the place that provides barrier-free housing with consideration of UD, complemented with community support facilities that cater the needs of diverse users especially PWD, and streetscapes that allow all buildings to be accessible by pedestrians.

\section{ii. Social and Cultural Life}

A universally designed living environment may also encourage participation and social interaction through the provision of flexible and adaptable spaces which can be shared by 
diverse users, for various activities, and at different times of the day. Woodcraft, Hackett \& Caistor-Arendar (2011) propose that a socially sustainable community needs to provide "shared spaces, collective activities and social architecture to foster local networks, belonging and community identity."

These spaces should be convivial as to attract people to gather and involve in the local community. Shaftoe (2008) establishes that a convivial and accessible place can attract more visitors to come and spend money at the place, thus, generate more income to the local vendors. The inclusive environment also intends to provide equal opportunities to all people including PWD to support participation and foster an interactive community (Gossett et al., 2009). An inclusive and convivial environment may not only create a fairer environment, but also a richer quality of life (Morrow, 2000), sense of belonging, as well as cultural enrichment.

\section{iii. Voice and Influence}

This component of social sustainability framework is more on the inclusive decision-making process and freedom of choices which allow all residents to take part in the planning and design process of the neighbourhood and community policy. This component resembles UD through capability approach that can be described as "what people are effectively able to do and be," (Robeyns, 2005) or as Alkire (2005) claims as ability "to enjoy valuable beings and doings." Oosterlaken (2009) implies that the capability sensitive design is originated from UD where broadest extent of users may be able to enjoy the environment they choose to have. Inclusive decision-making process gives opportunity for members of the community to voice their opinion, needs, and make important decision for the future of the community.

\section{iv. Space to Grow}

Participation and social interaction may also develop within the living space or the space to grow. The entire neighbourhood or city should be flexible and adaptable to the residents' life changing abilities so that they may be able to interact with other people and participate in the community over a lifetime (Woodcraft, Hackett \& Caistor-Arendar, 2011). In regards to the private living space, this study proposes that each home should be located within the vicinity of nearby houses, as to create an inviting atmosphere of the neighbourhood. To encourage visitability and social interaction over a lifespan, housings should also be conducive and welcoming through the provisions of UD solutions and the hospitality of the homeowners themselves.

\subsubsection{Social Development beyond the Framework}

Even though the framework is explained from the external component to the internal component by Woodcraft, Hackett \& Caistor-Arendar (2011), this study prefers to elaborate the framework starting from the core component (space to grow) to the outer component and beyond. As the social interaction and participation starts within a "space to grow", users have control over the community decision-making process through "voice and influence", thus, enable them to involve in "social and cultural life" while all these private and public spaces are connected by accessible "amenities and social infrastructure". These components then go beyond the framework by influencing pro-environmental behaviour which benefits 
ecological sustainability, and contributing to the local and regional economy to enhance economic sustainability. Thus, it can be said that a universally designed environment may contribute to social sustainability (as well as environmental and economic sustainability) by encouraging participation and social interaction within a livable society.

\subsection{Conclusion}

Considering UD's roles in sustaining well-being, safety and accessibility within the individual's living spaces, as well as encouraging participation and social interaction within a livable community, UD can be regarded as a significant component for social sustainability. UD may cater the needs of diverse users over a life time, therefore be able to sustain one's life throughout life changing abilities and support social development among all members of the society. In order to be socially sustainable, a person needs to be successfully developed as an individual, a family member and a part of the community.

The social aspect of sustainability should be emphasized in the mainstream discussion on sustainability because it influences human behaviour and quality of life in many ways. It is also recommended that early planning or designing for successful long term sustainable social life of new communities is equally important as planning for environmental and economic sustainability (Woodcraft, Hackett \& Caistor-Arendar, 2011). UD provisions should also be applied in the planning for sustainability as to create a smarter, greener and more livable future (Skoda Design \& Architecture, 2012).

More researches can be conducted to further investigate UD benefits to develop a more sustainable community by incorporating mixed-methods or methodological triangulation. By the end of this study, there rises a question of strategies to encourage sustainable ways of life or pro-environmental behaviour through architectural and interior design, which can be an interesting future research topic.

\section{Acknowledgement}

Researchers would like to thank the Research Management Institute (RMI) of UiTM Shah Alam for funding a research on UD implementation in public buildings which initiates this study's idea of UD relation to social sustainability.

\section{References}

Alkire, S. (2005). Why the Capability Approach? Journal of Human Development, 6(1), 115-133.

Askalen, F., Bergh, S., Bringa, O.R. and Heggem, E.K. (1997). Universal Design: Planning and design for all. GLADNET Collection, 12 January 1997. The Norwegian State Council on Disability.

Bramley, G., Dempsey, N., Power, S., Brown, C. and Watkins, D. (2009). Social Sustainability and Urban Form: Evidence from five British cities. Environment and Planning A, 41, 2125-2142. 
Choguill, C.L. (2008). Developing sustainable neighbourhoods. Habitat International, 32, 41-48.

Colantonio, A. (n.d.). Social Sustainability: Linking Research to Policy and Practice. Retrieved 27 January 2013 from http://ec.europa.eu/research/sd/conference/2009/papers/7/andrea_colantonio_-_social_sustainability.pdf

Dave, S. (2011). Neighbourhood Density and Social Sustainability in Cities of Developing Countries. Sustainable Development, 19, 189-205.

Dempsey, N., Bramley, G., Power, S., \& Brown, C. (2011). The social dimension of sustainable development: defining urban social sustainability. Sustainable Development, 19, 289-300.

Duncan, R. (2007). Universal Design - Clarification and Development. A Report for the Ministry of the Environments, Government of Norway, March 2007.

Gold Coast City Council (n.d.). Homewise Guide - Universal Design for comfort, safety, sustainability and style. Retrieved 28 November 2012 from

http://www.goldcoast.qld.gov.au/attachment/people_and_communities/homewise_guide_largefont.pdf

Gossett, A., Mirza, M., Barnds, A.K. and Feidt, D. (2009). Beyond Access: A case study on the intersection between accessibility, sustainability, and universal design. Disability and Rehabilitation: Assistive Technology, 4(6), 439-450.

Lawlor, D. (2012). Sustainable Design Begins with Universal Design. Retrieved 28 November 2012 from http://www.asid.org/designknowledge/aa/inplace/active/sustainableuniversal.htm

Morrow, R. (2000). Inclusion as a Critical Tool in Design Education, Proceedings of Designing for the 21 st Century, an International Conference on Universal Design. Retrieved 19 September 2012 from http://www.adaptenv.org/21 centruy/proceedings.asp

National Center for the Dissemination of Disability Research (NCDDR) (2004). Accessibility in Our Built Environment: Visitability. Focus, Technical Brief Number 8.

Oosterlaken, I. (2009). Design for Development: A Capability Approach. Design Issues, 25(4), 91-102.

Robeyns, I. (2005). The Capability Approach - A Theoretical Survey. Journal of Human Development, 6(1), 94-114.

Rosly, D. \& Hashim, N. (2011). Guideline and Framework for Green Township in Malaysia. Presentation. Federal Department of Town and Country Planning Department \& Malaysian Institute of Planners. Seminar on Sustainable Cities-Sharing Swedish Experience, 24 May 2011, Park Royal Hotel, Kuala Lumpur.

Shaftoe, H. (2008). Convivial Urban Spaces: Creating effective public places. Earthscan, UK and USA.

Sharifi, A. \& Murayama, A. (2012). Changes in the traditional urban form and the social sustainability of contemporary cities: A case study of Iranian cities. Habitat International. doi: 10.1016/j.habitatint.2012.05.007

Skoda Design \& Architecture (2012). Universal Design and Sustainability. Retrieved 28 November 2012 from http://www.skodadesign.com/universal-design-and-sustainability

Town and Country Planning Association (TCPA) (2009). Applying Inclusive Design Principles to eco-Town Development: Eco-towns inclusive design worksheet.

United Nations Research Institute for Social Development (UNRISD) (2011). Social Development in an Uncertain World (UNRISD Research Agenda 2010-2014).Retrieved 6 February 2013 from http://www.unrisd.org/80256B42004CCC77/(httplnfoFiles)/43BFA3387807E7E680257920004253C7/\$file/ResAge 10-14a.pdf 
Abdul Kadir, S.A., \& Jamaludin, M. / Asian Journal of Environment-Behaviour Studies (ajE-Bs), 3(9) Jul / Aug 2018 (p.183-192)

Weingaertner, C. and Moberg, $\AA$. (2011). Exploring Social Sustainability: Learning from perspectives on urban development and companies and products. Sustainable Development. doi:10.1002/sd.536.

Woodcraft, S., Hackett, T. and Caistor-Arendar, L. (2011). Design for Social Sustainability: A framework for creating thriving new communities. Future Communities.

World Commission on Environment and Development (1987). The Brundtland report: Our common future. Oxford: Oxford University Press. 